\title{
Diurnal Ruminal pH and Temperature Patterns of Steers Fed Corn or Barley-Based Finishing Diets
}

\author{
Hannah M. DelCurto-Wyffels ${ }^{1, *}$, Julia M. Dafoe ${ }^{2}$, Cory T. Parsons ${ }^{2}$, Darrin L. Boss ${ }^{2}$, Timothy DelCurto ${ }^{1}(\mathbb{D}$, \\ Samuel A. Wyffels ${ }^{2}{ }^{-1}$, Megan L. Van Emon ${ }^{1} \mathbb{D}$ and Janice G. P. Bowman ${ }^{1}(\mathbb{D}$ \\ 1 Department of Animal and Range Sciences, Montana State University, Bozeman, MT 59717, USA; \\ timothy.delcurto@montana.edu (T.D.); megan.vanemon@montana.edu (M.L.V.E.); \\ jbowman@montana.edu (J.G.P.B.) \\ 2 Northern Agricultural Research Center, Montana State University, Havre, MT 59501, USA; \\ jdafoe@montana.edu (J.M.D.); Cory.Parsons2@chsinc.com (C.T.P.); dboss@montana.edu (D.L.B.); \\ samwyffels@montana.edu (S.A.W.) \\ * Correspondence: hannah.delcurto@montana.edu
}

check for updates

Citation: DelCurto-Wyffels, H.M.; Dafoe, J.M.; Parsons, C.T.; Boss, D.L.; DelCurto, T.; Wyffels, S.A.; Van Emon, M.L.; Bowman, J.G.P. Diurnal Ruminal $\mathrm{pH}$ and Temperature Patterns of Steers Fed Corn or Barley-Based Finishing Diets. Animals 2021, 11, 2809. https://doi.org/ 10.3390/ani11102809

Received: 15 August 2021

Accepted: 24 September 2021

Published: 27 September 2021

Publisher's Note: MDPI stays neutral with regard to jurisdictional claims in published maps and institutional affiliations.

Copyright: (c) 2021 by the authors. Licensee MDPI, Basel, Switzerland. This article is an open access article distributed under the terms and conditions of the Creative Commons Attribution (CC BY) license (https:// creativecommons.org/licenses/by/ $4.0 /)$.
Simple Summary: Cattle in feedlots are typically fed diets with a high proportion of cereal grains. While feeding high-energy grain-based diets is advantageous for growth and performance, it can also contribute to an increased likelihood of metabolic issues. Different feedstuffs have unique digestive utilization, which may lead to different cattle performance outcomes. Barley is fermented to a greater extent in the rumen, compared to corn, and can lead to an increased likelihood of digestive disorders. To further our understanding of the use of barley and corn in cattle feedlot diets, we evaluated the effect of diets on ruminal $\mathrm{pH}$, temperature and feed intake events using continuous rumen monitoring technology. While mean ruminal $\mathrm{pH}$ was not different between corn or barley-fed steers, barley-fed steers had greater ruminal $\mathrm{pH}$ change throughout a $24 \mathrm{~h}$ period. Barley-fed steers also exhibited greater variation in ruminal $\mathrm{pH}$. Additionally, intake patterns were different between cornand barley-fed steers in which corn-fed steers consumed more feed the first $6 \mathrm{~h}$ directly after feeding while barley-fed steers consumed more feed later in the day. Presumably these intake patterns could be influenced by differences in the diurnal patterns of ruminal $\mathrm{pH}$ between corn and barley. By evaluating ruminal dynamics on a diurnal scale, we will enhance our understanding of utilization of different feedstuffs in beef feedlot diets.

Abstract: This study evaluated the effects of corn or barley finishing diets on ruminal $\mathrm{pH}$ and temperature and their relationship to feed intake events using continuous reticulorumen monitoring of feedlot steers. Average daily ruminal $\mathrm{pH}$ and temperature were not impacted $(p \geq 0.17)$ by diet. However, diet did affect daily variation of ruminal $\mathrm{pH}$ and temperature $(p<0.01)$. Average hourly ruminal $\mathrm{pH}$ displayed a diet by hour post-feeding interaction $(p<0.01)$, where barley-fed steers had greater $(p<0.01)$ ruminal $\mathrm{pH}$ than corn-fed steers at $0,1,18,19,20,21,22$ and $23 \mathrm{~h}$ post feeding, but had lower $(p \leq 0.05)$ ruminal $\mathrm{pH}$ than corn-fed steers at 6,7 , and $8 \mathrm{~h}$ post-feeding. Variation in ruminal $\mathrm{pH}$ hour post-feeding also displayed a diet by hour post-feeding interaction $(p<0.01)$, where barley-fed steers had greater $(p \leq 0.03)$ variation in ruminal $\mathrm{pH}$ at hours $1-17$ post-feeding but did not differ $(p \geq 0.16)$ at $0,18,19,20,21,22$ and $23 \mathrm{~h}$ post-feeding. Additionally, average hourly ruminal temperature exhibited a diet by hour post-feeding interaction $(p<0.01)$. In summary, basal grain interacted with time post-feeding influencing ruminal $\mathrm{pH}$ and temperature in feedlot steers.

Keywords: barley; corn; intake; ruminal pH; ruminal temperature; steer

\section{Introduction}

Feedlot cattle are often fed a diet with a high proportion of cereal grains to meet the energy requirements necessary for targeted growth and performance. Numerous grains may be utilized in cattle feedlot rations. In the United States, corn is the most common 
grain ingredient in feedlots [1]. However, barley is more adapted to the growing conditions of northern regions and, as a result, is a common feed grain in finishing rations in Canada and the Pacific Northwest [2].

While feeding high concentrate-based rations of rapidly fermentable carbohydrates favors growth and performance, it does come with the challenge of increased likelihood of metabolic disorders such as acidosis [3]. Digestive disorders account for approximately $25 \%$ to $33 \%$ of deaths in the feedlot and can have a marked impact on cattle health and efficiency of production [4]. The grain source used in feedlot rations can have an influence on both rumen environment and function [5]. In particular, barley starch is more rapidly fermented and digested to a greater extent in the rumen compared to corn $[6,7]$. Thus, the use of barley in finishing rations has been criticized due to the increased likelihood of metabolic disorders and reduced performance $[3,5]$.

In an ideal rumen environment for grain-fed cattle, ruminal fermentation is stable and mean ruminal $\mathrm{pH}$ is generally greater than 5.5, often ranging from 5.8 to 6.5 [8]. Typically, ruminal $\mathrm{pH}$ of grain-fed cattle follows a diurnal pattern in which ruminal $\mathrm{pH}$ is often high before the morning feeding and declines after feeding through peak fermentation [9]. However, the extent of ruminal $\mathrm{pH}$ decline is dependent on the size and fermentability of the meal $[9,10]$. Ruminal $\mathrm{pH}$ is a critical factor for rumen function due to the impact of $\mathrm{pH}$ on microbial populations, products of fermentation, as well as the physiological function of the rumen including motility and absorption $[8,11]$. When ruminal $\mathrm{pH}$ drops below 5.6 there is often a shift in microbial populations toward lactic acid production, which will continue to reduce ruminal $\mathrm{pH}$, resulting in acidosis [8]. Recent research has demonstrated that low ruminal $\mathrm{pH}$ is also associated with increased ruminal temperature [12,13], establishing an importance for monitoring rumen temperature for determining animal health and early detection of disease [14].

Diet composition and ruminal microbial populations play a large role in digestion and therefore, the efficiency of cattle performance [8]. The digestive characteristics of barley and corn grains could potentially influence ruminal environment and cattle dry matter intake. However, the effects of intake on gastrointestinal function in cattle are less understood [15]. Moreover, information relating individual intake to ruminal environment of animals on barley- or corn-based diets is limited. Therefore, the objective of this study was to evaluate the effects of corn or barley finishing diets on ruminal $\mathrm{pH}$, temperature and feed intake events of feedlot steers using continuous rumen monitoring.

\section{Materials and Methods}

All animals used in this study were provided by the Northern Agricultural Research Center, a unit of the Montana Agricultural Experiment Station, (Havre, MT, USA; Montana; $\left.48.5500^{\circ} \mathrm{N}, 109.6841^{\circ} \mathrm{W}\right)$. Experimental design and procedures were approved by the Agriculture Animal Care and Use Committee of Montana State University (\#2016-AA26).

Experimental design and diets have been published previously in DelCurto-Wyffels et al. [16]. Briefly, Angus-based yearling steer calves were fed in a feedlot study from 27 February 2017, to 12 June 2017 (105 days; $427.3 \pm 3.7 \mathrm{~kg} ; n=48$ ) in year 1, and 26 February 2018, to 11 June 2018 (105 days; $406.8 \pm 3.4 \mathrm{~kg} ; n=47$ ) in year 2 . All steers were implanted at the initiation of this study (Synovex One Feedlot Implant; Zoetis, Parsippany-Troy Hills, NJ, USA). Upon entry to the feedlot, steers were stratified by body weight (BW) and, within stratum, randomly assigned to one of two primary basal grain dietary treatments, including (1) Grade 2 feed corn or (2) Hockett barley. Hockett is a two-row malting barley that is very stable under dryland conditions and often used as a livestock feed source when malting parameters are not met [17]. Both barley and corn grains were dry-rolled and provided as a total mixed ration (Table 1 ). The diets averaged $10.28 \%$ crude protein and $0.24 \mathrm{Mcal} \cdot \mathrm{kg}^{-1}$ net energy gain. Prior to the data collection period, steers were acclimated to their respective diet for 14 days. Steers were fed once daily at 0800 and rations were provided to attain maximum individual intake without excessive wastage. Diets were increased by $0.23 \mathrm{~kg}$ per head after clean bunks had been present by midday for two 
consecutive days. Feed refusals were weighed and removed weekly. All animals had ad libitum access to water for the entirety of the trial.

Table 1. Ingredient composition of finishing diets containing corn or Hockett barley as basal grains.

\begin{tabular}{ccc}
\hline & Barley & Corn \\
\hline Ingredient & - & \\
Corn, $\%$ & 80.00 & 80.00 \\
Barley, $\%$ & 12.00 & - \\
Barley straw, $\%$ & 3.00 & 12.00 \\
Canola oil, $\%$ & 5.00 & 3.00 \\
Supplement, $\%{ }^{1}$ & 5.00 \\
\hline
\end{tabular}

${ }^{1}$ The supplement composition was formulated based on initial basal grain nutrient analysis and designed to make diets similar in crude protein, minerals and vitamins.

Steers were fitted with an electronic identification ear tag and were adapted to a GrowSafe system (GrowSafe Systems Ltd., Airdrie, AB, Canada) for 14 days prior to the start of this study. A total of 24 GrowSafe electronic feed bunks (12 per treatment; 1 per 2 steers) were used in this study, each equipped with an antenna to detect animal presence. Neck bars on feed bunks only allowed for one animal entry to a bunk at a time. Individual animal intake was continuously recorded with load cells measurements via wireless transfer to a data-acquisition computer. The system was monitored daily for unaccounted feed balance. Whenever unaccounted feed disappearance was greater than $5 \%$ the GrowSafe system deemed the $24 \mathrm{~h}$ data collection period as failed. In our study, $8.54 \%$ and $10.92 \%$ of the dry matter intake data failed in year 1 and 2 , respectively. Previous research with GrowSafe technology has suggested that the accuracy of dry matter intake was not impacted when up to $30 \%$ of the data were missing [18].

To determine ruminal $\mathrm{pH}$ and temperature, an indwelling wireless data transmitting system (SmaXtec ${ }^{\circledR}$ Animal Care GmbH, Graz, Austria) was used [19]. A SmaXtec bolus was administered to 12 steers per treatment group for each year of this study. The $\mathrm{pH}$ probes were calibrated using $\mathrm{pH} 4$ and $\mathrm{pH} 7$ buffer solutions. According to directions of the manufacturer, the boluses were inserted into the reticulorumen of the steers at the initiation of this study. SmaXtec animal care technology ${ }^{\circledR}$ enables the continuous real-time display of data such as ruminal $\mathrm{pH}$ and temperature. The data were read every $10 \mathrm{~min}$ throughout the entirety of this study and all data were obtained by smaXtec messenger ${ }^{\circledR}$ computer software.

Average daily intake and intake behavior are presented in a companion study [16]. GrowSafe data were used to calculate intake for each individual steer each hour postfeeding on a daily basis. The length of time between intake readings that constitute a new intake event was predetermined as 300 s [20-22]. Hourly intake and intake event data were then paired with the ruminal $\mathrm{pH}$ and temperature readings for each individual steer for the duration of both study years (Table S1). Daily and hourly variation in ruminal $\mathrm{pH}$ and temperature, measured as coefficient of variation $(\mathrm{CV}, \%)$, was based on SmaXtec bolus data for each individual. Data were then used to evaluate ruminal $\mathrm{pH}$ and temperature change post-feeding and post-intake event and the variation of ruminal $\mathrm{pH}$ and temperature post-feeding.

All statistical analyses were performed in $\mathrm{R} 4.0 .3$ [23]. Average daily ruminal $\mathrm{pH}$, temperature, and coefficient of variation $(\mathrm{CV}, \%)$ of daily ruminal $\mathrm{pH}$ and temperature were analyzed using ANOVA (the car package; [24]) with a generalized linear mixed model (the lme4 package; [25]) including diet as the fixed effect, with year and individual steer as random intercepts. Prior to evaluating the effects of diet on diurnal ruminal $\mathrm{pH}$ and temperature change, we conducted a Pearson's correlation test to evaluate the relationship between ruminal $\mathrm{pH}$ and temperature. However, preliminary results suggest that there was little relationship between ruminal $\mathrm{pH}$ and temperature for both barley- and cornfed steers $\left(\mathrm{r}^{2}=-0.02\right.$ and -0.01 , respectively). Therefore, ruminal $\mathrm{pH}$ and temperature were both included in the final analysis and analyzed independently. Post-feeding hourly 
intake and ruminal $\mathrm{pH}, \mathrm{pH} \mathrm{CV}$, ruminal temperature and temperature $\mathrm{CV}$ were analyzed using ANOVA (the car package; [24]) with a generalized linear mixed model (the lme4 package; [25]) including diet, hour post-feeding and the interaction of diet and hour postfeeding as fixed effects, with year and individual steer as random intercepts. Ruminal $\mathrm{pH}$ and temperature post-feed intake event were analyzed using ANOVA (the car package; [24] with a generalized linear mixed model (the lme4 package; [25] including fixed effects of diet, minutes post-intake event and the interaction of diet and minutes post-intake event and random intercepts of year and individual steer. To account for autocorrelation of repeated measurements, individual steer was used as a random intercept in all analyses. To satisfy assumptions of normality and homogeneity of variance, data were plotted and log transformed if needed. Significance was considered at an alpha $\leq 0.05$ and tendencies were considered at an alpha $\leq 0.10$. Mean separation was conducted using the Tukey method when $p<0.05$ (the emmeans package; [26]). Experimental unit was individual steer.

\section{Results}

Average daily ruminal $\mathrm{pH}$ and temperature were not impacted ( $p \geq 0.17$; Table 2$)$ by diet. However, diet did affect daily variation of ruminal $\mathrm{pH}$ and temperature $(p<0.01)$, where barley-fed steers exhibited 1.74 and $0.25 \%$ greater daily variation of $\mathrm{pH}$ and temperature, respectively, compared to corn-fed steers. Average hourly intake $(\mathrm{kg})$ post-feeding displayed a diet by hour post-feeding interaction $(p<0.01$; Figure 1$)$, where corn-fed steers consumed more feed $(p \leq 0.01)$ than barley-fed steers at $0,1,2,5$, and $6 \mathrm{~h}$ post-feeding and tended $(p \leq 0.08)$ to consume more feed than barley-fed steers at hours 3 and 4 post-feeding. However, barley-fed steers consumed more feed $(p \leq 0.03)$ than corn-fed steers at 10, 11 and $22 \mathrm{~h}$ post-feeding.

Table 2. Daily dry matter intake, ruminal $\mathrm{pH}$ and temperature of steers consuming diets containing corn or Hockett barley as basal grains at the Northern Agricultural Research Center, Havre, MT, USA.

\begin{tabular}{|c|c|c|c|c|}
\hline Item & Barley & Corn & SEM $^{1}$ & $p$-Value \\
\hline Average daily intake, $\mathrm{kg}^{2}$ & 11.30 & 11.72 & 0.52 & 0.06 \\
\hline Average daily ruminal $\mathrm{pH}$ & 6.46 & 6.43 & 0.14 & 0.46 \\
\hline Daily ruminal $\mathrm{pH} \mathrm{CV}, \% 3$ & 5.63 & 3.89 & 0.14 & $<0.01$ \\
\hline Average daily ruminal temperature, ${ }^{\circ} \mathrm{C}$ & 39.22 & 39.35 & 0.08 & 0.17 \\
\hline Daily ruminal temperature $\mathrm{CV}, \%$ & 2.37 & 2.12 & 0.10 & $<0.01$ \\
\hline
\end{tabular}

${ }^{1}$ SEM $=$ standard error of the means. ${ }^{2}$ Average daily intake (kg) originally presented in DelCurto-Wyffels [16] ${ }^{3} \mathrm{CV}=$ coefficient of variation.

Average hourly ruminal $\mathrm{pH}$ displayed a diet by hour post-feeding interaction $(p<0.01$; Figure 2). Barley-fed steers had greater $(p<0.01)$ ruminal $\mathrm{pH}$ than corn-fed steers at 0,1 , $18,19,20,21,22$, and $23 \mathrm{~h}$ post-feeding and tended $(p=0.07)$ to be greater than corn-fed steers $2 \mathrm{~h}$ post-feeding, but had lower $(p \leq 0.05)$ ruminal $\mathrm{pH}$ than corn-fed steers at 6,7 , and $8 \mathrm{~h}$ post-feeding and tended $(p=0.06)$ to be lower than corn-fed steers at 9,10 , and $11 \mathrm{~h}$ post-feeding. Additionally, variation in ruminal $\mathrm{pH}$ hour post-feeding also displayed a diet by hour post-feeding interaction $(p<0.01$; Figure 3$)$, where barley-fed steers had greater $(p \leq 0.03)$ variation in ruminal $\mathrm{pH}$ at hours $1-17$ post-feeding but did not differ from corn-fed steers ( $p \geq 0.16)$ at $0,18,19,20,21,22$, and $23 \mathrm{~h}$ post-feeding. Suggesting that barley-fed steers had greater decline in $\mathrm{pH}$ post-feeding and greater variation in ruminal $\mathrm{pH}$ than corn-fed steers. 


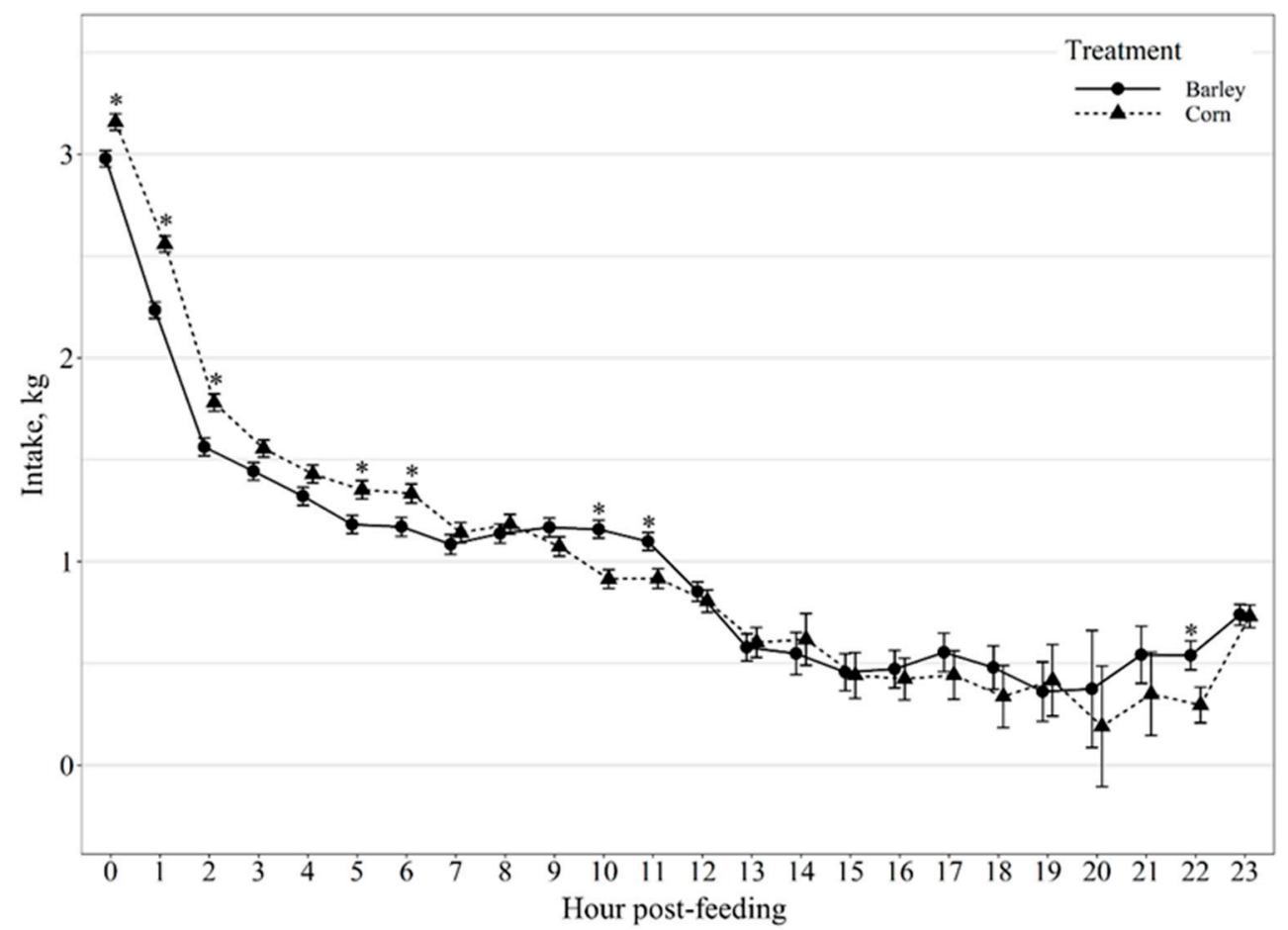

Figure 1. Diurnal dry matter intake patterns of beef steers fed once daily (0800) barley- or corn-based feedlot diets. Intake was influenced by diet $\times$ hour post-feeding interaction $(p<0.01)$ and differences $(p \leq 0.05)$ within hour post-feeding are denoted by *.

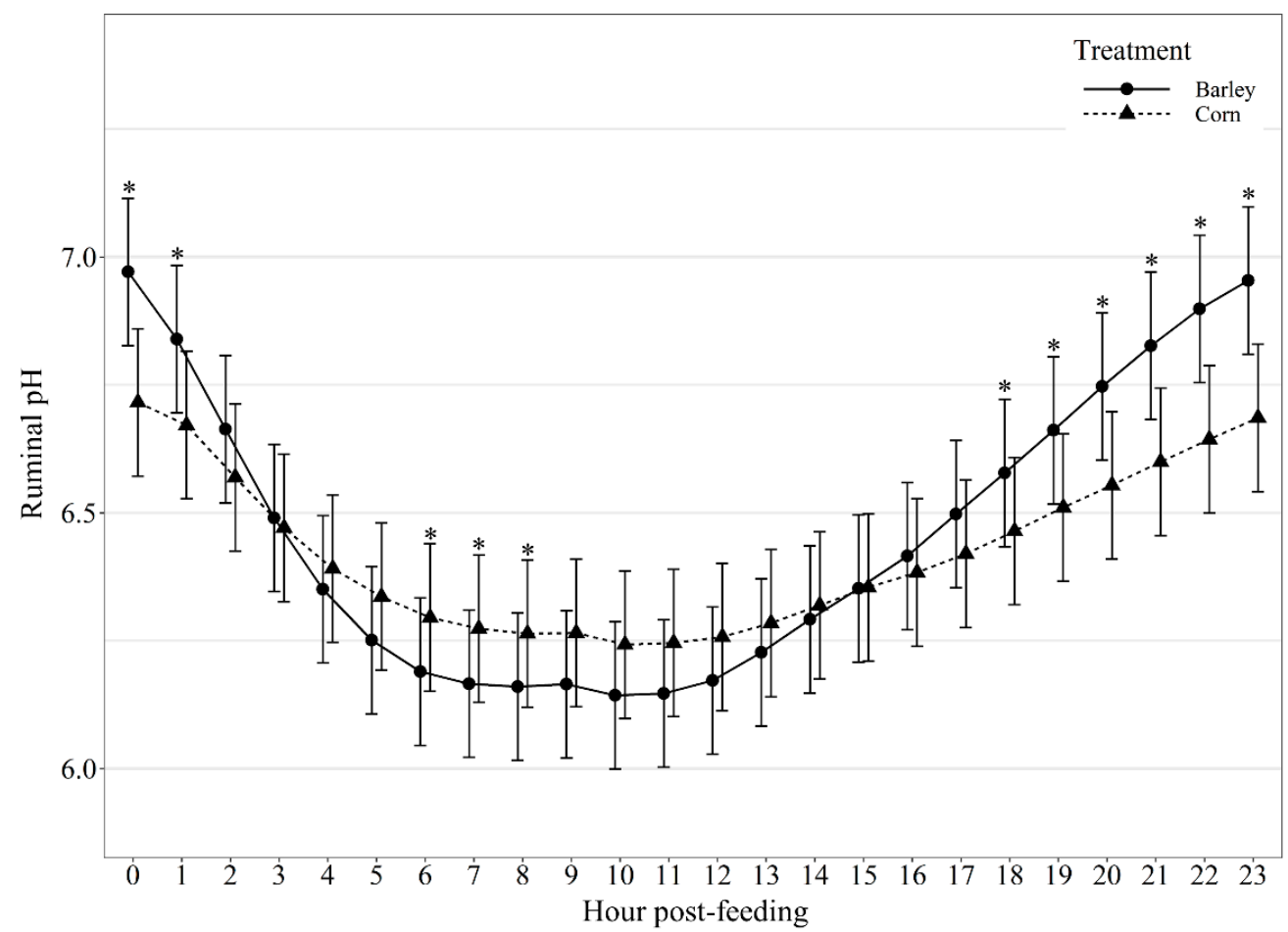

Figure 2. Diurnal pH patterns of beef steers fed once daily (0800) barley- or corn-based feedlot diets. Ruminal $\mathrm{pH}$ was influenced by diet $\times$ hour post-feeding interaction $(p<0.01)$ and differences $(p \leq 0.05)$ within hour post-feeding are denoted by * 


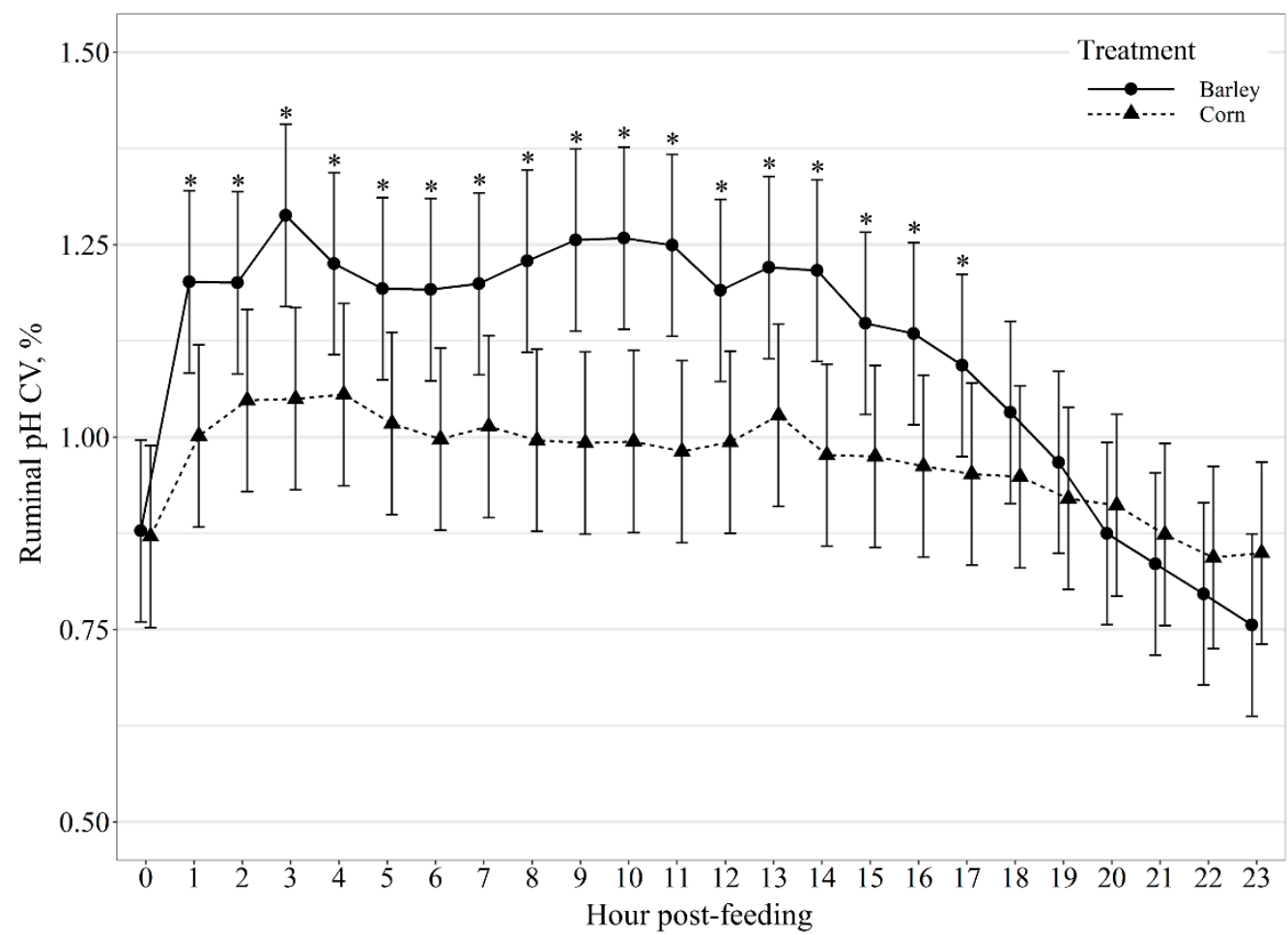

Figure 3. Diurnal $\mathrm{pH}$ coefficient of variation (CV, \%) patterns of beef steers fed once daily (0800) barley- or corn-based feedlot diets. Ruminal $\mathrm{pH} \mathrm{CV}$ was influenced by diet $\times$ hour post-feeding interaction $(p<0.01)$ and differences $(p \leq 0.05)$ within hour post-feeding are denoted by *.

Average hourly ruminal temperature exhibited a diet by hour post-feeding interaction $(p<0.01$; Figure 4$)$, with corn-fed steers having greater $(p \leq 0.01)$ ruminal temperature at 0,1 , and $23 \mathrm{~h}$ and tended $(p \leq 0.10)$ to have greater ruminal temperature at $4,18,21$ and $22 \mathrm{~h}$ post-feeding. Variation in ruminal temperature hour post-feeding also displayed a diet by hour post-feeding interaction $(p<0.01$; Figure 5$)$, where corn-fed steers had greater $(p=0.02)$ variation in ruminal temperature at $2 \mathrm{~h}$ post-feeding than barley-fed steers; however, barley-fed steers had greater $(p \leq 0.02)$ variation in ruminal temperature than corn-fed steers at $3,4,5,7,8,9,10,11,15,16,17$ and $18 \mathrm{~h}$ post-feeding.

Ruminal $\mathrm{pH}$ post-intake event displayed a diet by minute post-intake event interaction $(p<0.01$; Figure 6); however, post hoc mean separation displayed no diet effects $(p \geq 0.63)$ on ruminal $\mathrm{pH}$ within minute post-intake event. Similarly, ruminal temperature post-intake event also exhibited a diet by minute post-intake event interaction $(p<0.01$; Figure 7$)$; however, post hoc means separation displayed no diet effects $(p \geq 0.11)$ on ruminal temperature within minute post-intake event. 


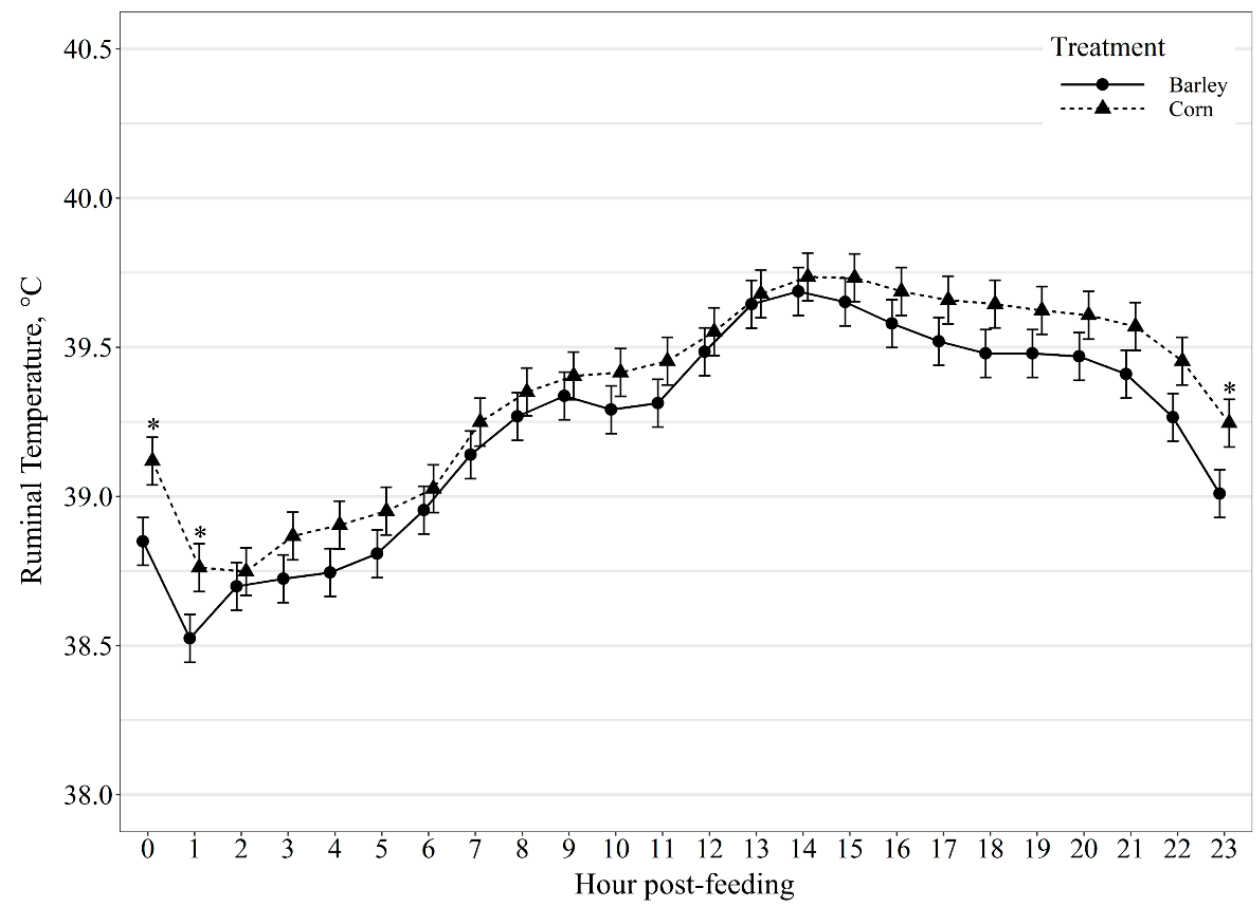

Figure 4. Diurnal ruminal temperature $\left({ }^{\circ} \mathrm{C}\right)$ patterns of beef steers fed once daily $(0800)$ barleyor corn-based feedlot diets. Ruminal temperature was influenced by diet $\times$ hour post-feeding interaction $(p<0.01)$ and differences $(p \leq 0.05)$ within hour post-feeding are denoted by *.

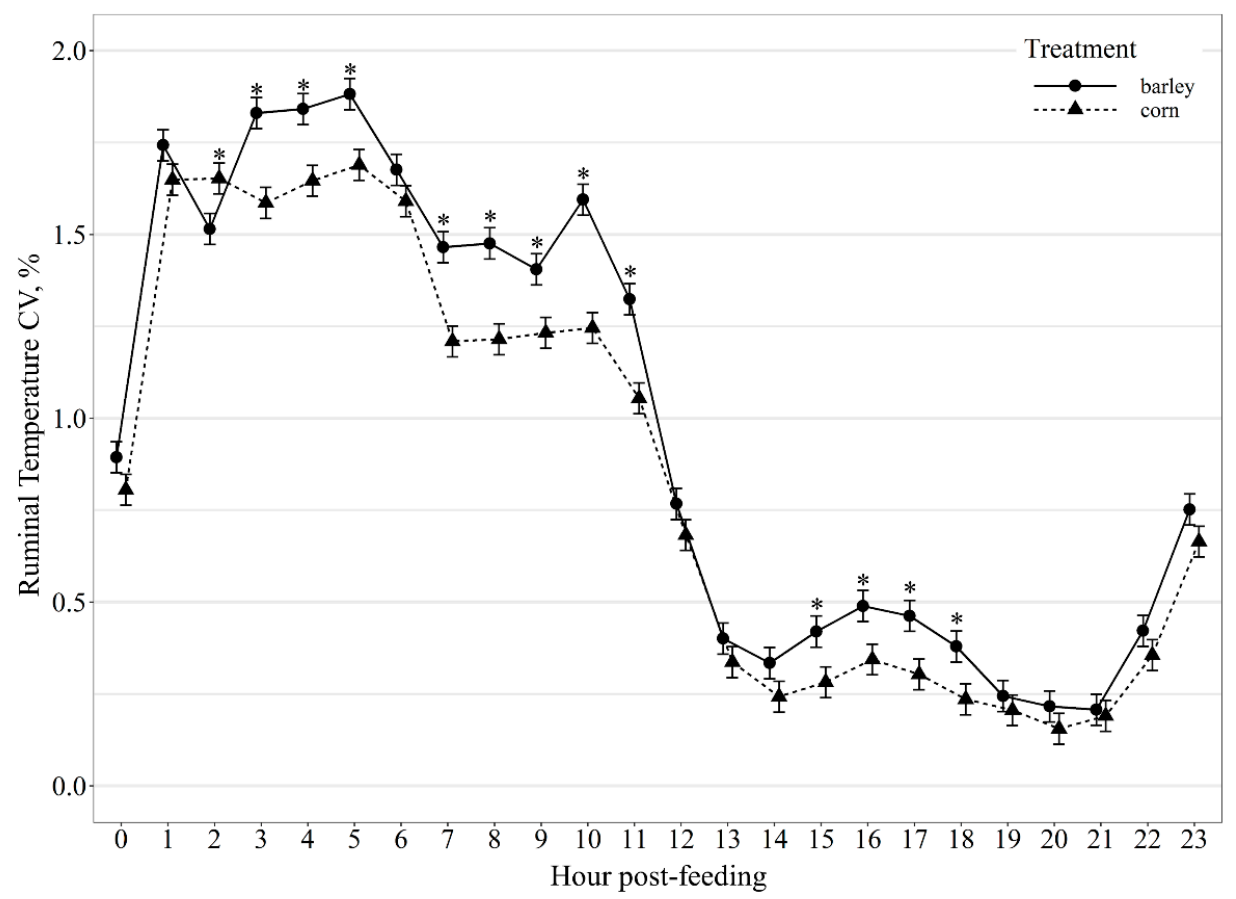

Figure 5. Diurnal ruminal temperature coefficient of variation $(\mathrm{CV}, \%)$ patterns of beef steers fed once daily (0800) barley- or corn-based feedlot diets. Ruminal temperature CV was influenced by diet $\times$ hour post-feeding interaction $(p<0.01)$ and differences $(p \leq 0.05)$ within hour post-feeding are denoted by *. 


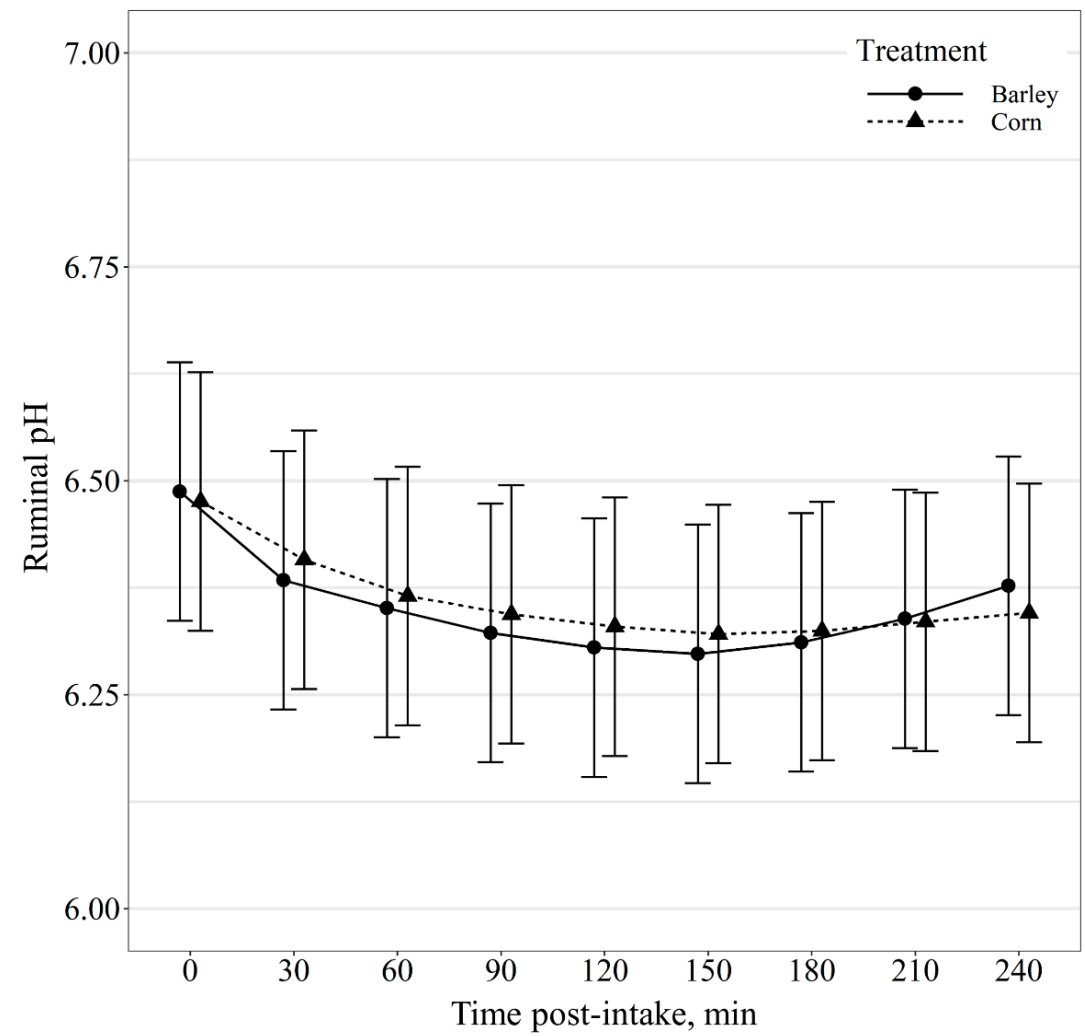

Figure 6. Ruminal $\mathrm{pH}$ change as a function of time ( $\mathrm{min}$ ) relative to intake event of beef steers provided barley- or corn-based feedlot diets. Ruminal $\mathrm{pH}$ was influenced by a diet $\times$ minute postintake event interaction ( $p<0.01)$; however, no differences $(p \geq 0.63)$ were observed between diets within post-intake event time periods.

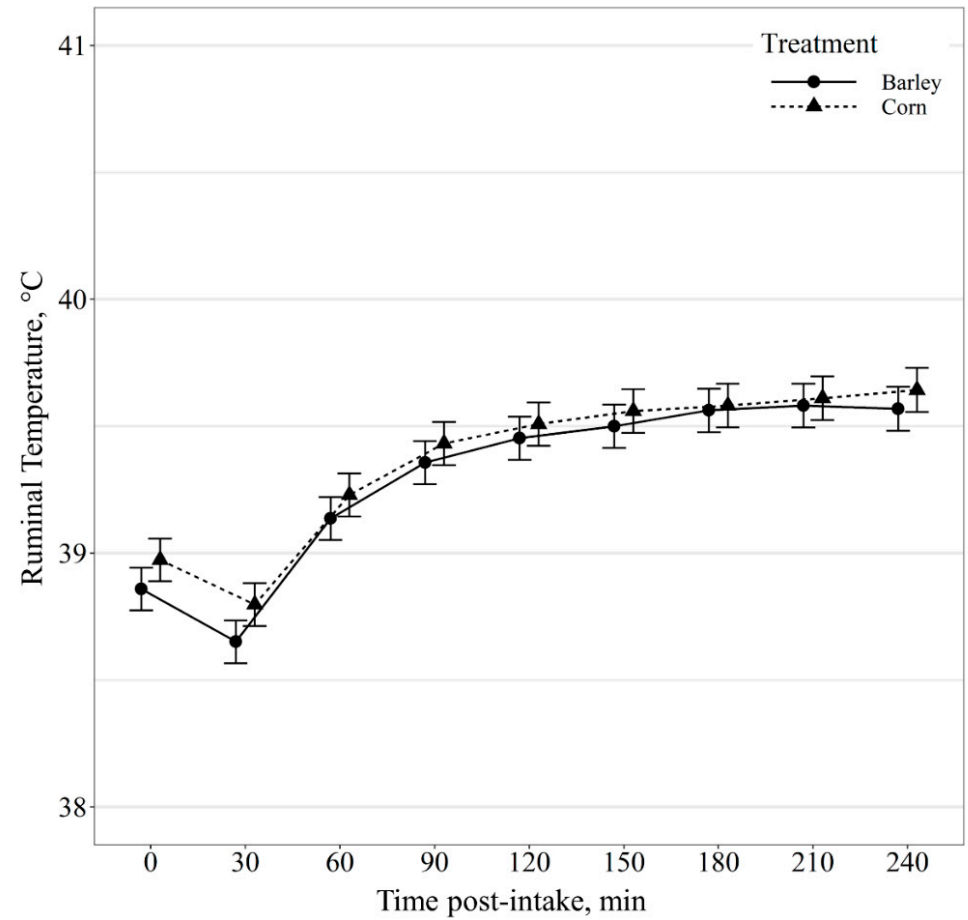

Figure 7. Ruminal temperature $\left({ }^{\circ} \mathrm{C}\right)$ change as a function of time (min) relative to intake event of beef steers provided barley- or corn-based feedlot diets. Ruminal temperature was influenced by a diet $\times$ minute post-intake event interaction $(p<0.01)$; however, no differences $(p \geq 0.11)$ were observed between diets within post-intake event time periods. 


\section{Discussion}

In the United States, the majority of cattle in feedlots are fed a grain-based diet [1]. The feedstuff utilized can impact cattle performance, rumen dynamics and digestive efficiency. In addition, the intake of fermentable carbohydrates coupled with the rate of fermentation can impact ruminal $\mathrm{pH}$. Barley and corn are two commonly used feeds for cattle; however, the digestive utilization of each grain can be quite different. Generally, corn has a greater starch content than barley and the starch is more likely to escape ruminal digestion and be absorbed in the small intestine [6]. Because starch digestion in the rumen is greater for barley than corn it has been demonstrated that cows fed diets containing barley tend to have a ruminal $\mathrm{pH} 0.2$ units lower than cows fed corn when fed the same amount of forage fiber [10]. In our study, we did not observe a difference in daily mean ruminal $\mathrm{pH}$ between barley and corn-fed steers and mean ruminal $\mathrm{pH}$ for steers fed both diets were well above acidotic conditions. However, nutritionists commonly attribute metabolic disturbances to large daily shifts in feeding behavior and erratic feed intake by cattle $[27,28]$. The size, number, and frequency of meals can have a large effect on ruminal $\mathrm{pH}$ [27] with low ruminal $\mathrm{pH}$ further contributing to erratic intake patterns [29]. A companion study evaluating the effect of corn- and barley-based diets on intake behavior and performance using the same steers, demonstrated a tendency for corn-fed steers to consume more feed per day and have greater variation in intake per day than barley-fed steers, but showed no differences in number and frequency of meals [16]. However, the differences in regard to intake patterns were not manifested in average daily ruminal $\mathrm{pH}$.

Generally, ruminal $\mathrm{pH}$ is highest just before the morning feeding. After feeding, the $\mathrm{pH}$ drops in relationship to fermentation of dietary carbohydrates $[10,27]$. Although we did not observe a difference in mean daily $\mathrm{pH}$ between barley and corn-fed steers, barley-fed steers displayed greater variation in daily ruminal $\mathrm{pH}$ and greater variation in ruminal $\mathrm{pH}$ for the majority of hours post-feeding (hours 1-17) compared to corn-fed steers. These findings could be due to the difference in starch availability and rate of fermentation between the two feedstuffs. Corn starch is less ruminally digestible [6] with up to $30 \%$ of corn starch escaping ruminal fermentation. Corn also has a slower rate of in situ dry matter and starch disappearance [30]. The slower rate of ruminal digestion of corn-based diets reduces the risk of low reticulorumen $\mathrm{pH}$ and may allow for the more stable diurnal $\mathrm{pH}$ observed in our study.

Previous research has reported a strong correlation between feed intake of feedlot cattle and the lowest daily ruminal $\mathrm{pH}$ on the previous day [31]. Yang et al. [32] observed that ruminal $\mathrm{pH}$ was higher in cows fed a corn-based diet compared to barley throughout the early portions of the day post-feeding. However, the magnitude of difference in ruminal $\mathrm{pH}$ between barley and corn-based diets were relatively small [32,33]. In our study, both corn- and barley-fed steers exhibited the majority of daily intake the first $12 \mathrm{~h}$ post-feeding, with corn-fed steers consuming or tending to consume more feed than barley-fed steers within the first $6 \mathrm{~h}$ post-feeding; however, barley-fed steers consumed more feed than corn-fed steers at hour 10 and 11 post-feeding and immediately prior to the next feeding event at $22 \mathrm{~h}$. Additionally, we found a diurnal difference in ruminal $\mathrm{pH}$ between barley and corn-fed steers in which ruminal $\mathrm{pH}$ was higher in barley-fed steers 0 and $1 \mathrm{~h}$ postfeeding, as well as, 18-23 h post-feeding and lower than corn-fed cattle at hour 6, 7, and 8 post-feeding. Thus, the ruminal $\mathrm{pH}$ for barley-fed steers had greater daily ruminal $\mathrm{pH}$ declines compared to corn-fed steers. Previous research has found that cattle consuming high levels of barley alter feeding behavior in a manner that reduces the risk of acidosis [34]. These findings suggest that animals may adjust their intake when $\mathrm{pH}$ is low, presumably in an attempt to limit consumption of fermentable carbohydrates and restore $\mathrm{pH}$ conditions to a more comfortable level [27]. This may explain why diet had an effect on diurnal ruminal $\mathrm{pH}$ patterns but was not a factor influencing ruminal $\mathrm{pH}$ post-intake event out to $240 \mathrm{~min}$.

Previous research has demonstrated ruminal temperature to be a reliable measure of body temperature in both dairy cows and beef steers [14,35]. Thus, monitoring ruminal temperature could aid in detecting adverse health events in cattle [14]. Additionally, a 
correlation has been observed between rumen temperature and $\mathrm{pH}[12,36]$. The strength of this relationship, however, appeared to be influenced by diet composition and individual animal variability [36]. In the current study, rumen temperature responded similarly in both barley and corn-fed cattle apart from the hour before and after feeding. There was no difference in ruminal temperature post-intake events between barley and corn-based diets. However, for steers fed barley- or corn-based diets, rumen temperatures declined 30 min post-intake event. Rumen temperatures are impacted by other factors such as water intake $[37,38]$. Presumably, the reduced temperatures observed $30 \mathrm{~min}$ post-intake could be due to cattle consuming water after feeding. Previous research has predicted watering events based on ruminal temperature change recorded with rumen boluses; however, this comes with a large margin of error [39]. Therefore, the relationship of rumen $\mathrm{pH}$ and temperature with water intake and intake behavior warrants further investigation.

\section{Conclusions}

Barley and corn are two commonly used grain sources in beef cattle diets. However, digestive utilization of each feedstuff and subsequent rumen environment of cattle fed barley- or corn-based diets can be markedly different. While mean ruminal $\mathrm{pH}$ was not different between corn or barley-fed steers, barley-fed steers had greater ruminal $\mathrm{pH}$ change throughout a $24 \mathrm{~h}$ period. Additionally, barley-fed steers had greater diurnal variation in ruminal $\mathrm{pH}$ up to hour 17 post-feeding. These findings are likely due to differences in starch content and rate of fermentation of the grains. Intake patterns were also unique in corn- and barley-fed steers in which corn-fed steers consumed more feed the first $6 \mathrm{~h}$ directly after feeding. Barley-fed steers, however, consumed more feed later in the day. Presumably these intake patterns could be influenced by ruminal $\mathrm{pH}$. Our research suggests that evaluating intake and ruminal fermentation characteristics needs to be conducted at a diurnal scale to optimize beef cattle performance and efficiency.

Supplementary Materials: The following are available online at https:/ / www.mdpi.com/article/ 10.3390/ani11102809/s1. Table S1: Animal Intake and Ruminal pH and Temperature Data.

Author Contributions: Conceptualization, H.M.D.-W., T.D., S.A.W., D.L.B. and J.G.P.B.; Methodology, H.M.D.-W., T.D., S.A.W., D.L.B. and J.G.P.B.; Formal Analysis, H.M.D.-W. and S.A.W.; Investigation, H.M.D.-W., D.L.B., T.D., S.A.W., M.L.V.E. and J.G.P.B.; Resources, D.L.B., T.D. and J.G.P.B.; Data Curation, H.M.D.-W., J.M.D., C.T.P., T.D. and S.A.W.; Writing-Original Draft Preparation, H.M.D.-W.; Writing-Review and Editing, H.M.D.-W., D.L.B., T.D., S.A.W., M.L.V.E. and J.G.P.B.; Visualization, H.M.D.-W. and S.A.W.; Supervision, D.L.B., T.D., M.L.V.E. and J.G.P.B.; Project Administration, H.M.D.-W.; Funding Acquisition, D.L.B., T.D. and J.G.P.B. All authors have read and agreed to the published version of the manuscript.

Funding: This research was funded by the Montana State University Northern Agricultural Research Center, Montana Agricultural Experiment Stations, and the Nancy Cameron Endowment.

Institutional Review Board Statement: This study was approved by the Agriculture Animal Care and Use Committee of Montana State University (\#2016-AA26).

Informed Consent Statement: Not applicable.

Data Availability Statement: The data presented in this study are available in Table S1.

Conflicts of Interest: The authors declare no conflict of interest.

\section{References}

1. Samuelson, K.L.; Hubbert, M.E.; Galyean, M.L.; Loest, C. Nutritional recommendations of feedlot consulting nutritionists: The 2015 New Mexico State and Texas Tech University survey. J. Anim. Sci. 2016, 94, 2648-2663. [CrossRef] [PubMed]

2. Bowman, J.G.P. Barley for beef cattle. In Cow-Calf Management Guide. Nutrition Section, 2nd ed.; Western Beef Resource Committee; JRAdams Publishing: Moscow, ID, USA, 2001; Volume 332, pp. 1-5.

3. Owens, F.N.; Secrist, D.S.; Hill, W.J.; Gill, D.R. Acidosis in cattle: A review. J. Anim. Sci. 1998, 76, 275-286. [CrossRef]

4. Galyean, M.L.; Rivera, J.D. Nutritionally related disorders affecting feedlot cattle. Can. J. Anim. Sci. 2003, 83, 13-20. [CrossRef] 
5. Owens, F.N.; Secrist, D.S.; Hill, W.J.; Gill, D.R. The effect of grain source and grain processing on performance of feedlot cattle: A review. J. Anim. Sci. 1997, 75, 868-879. [CrossRef]

6. Ørskov, E.R. Starch Digestion and Utilization in Ruminants. J. Anim. Sci. 1986, 63, 1624-1633. [CrossRef]

7. Herrera-Saldana, R.; Huber, J.; Poore, M. Dry Matter, Crude Protein, and Starch Degradability of Five Cereal Grains. J. Dairy Sci. 1990, 73, 2386-2393. [CrossRef]

8. Nagaraja, T.G.; Titgemeyer, E.C. Ruminal acidosis in beef cattle: The current microbiological and nutritional outlook. J. Dairy Sci. 2007, 90, E17-E38. [CrossRef]

9. Nocek, J.; Allman, J.; Kautz, W. Evaluation of an Indwelling Ruminal Probe Methodology and Effect of Grain Level on Diurnal pH Variation in Dairy Cattle. J. Dairy Sci. 2002, 85, 422-428. [CrossRef]

10. Beauchemin, K.A. Managing rumen fermentation in barley based diets: Balance between high production and acidosis. Adv. Dairy Technol. 2000, 12, 109-125.

11. Elam, C.J. Acidosis in Feedlot Cattle: Practical Observations. J. Anim. Sci. 1976, 43, 898-901. [CrossRef] [PubMed]

12. Wahrmund, J.L.; Ronchesel, J.R.; Krehbiel, C.R.; Goad, C.L.; Trost, S.M.; Richards, C.J. Ruminal acidosis challenge impact on ruminal temperature in feedlot cattle. J. Anim. Sci. 2012, 90, 2794-2801. [CrossRef]

13. AlZahal, O.; Kebreab, E.; France, J.; Froetschel, M.; McBride, B. Ruminal Temperature May Aid in the Detection of Subacute Ruminal Acidosis. J. Dairy Sci. 2008, 91, 202-207. [CrossRef]

14. Rose-Dye, T.K.; Burciaga-Robles, L.O.; Krehbiel, C.R.; Step, D.L.; Fulton, R.W.; Confer, A.W.; Richards, C.J. Rumen temperature change monitored with remote rumen temperature boluses after challenges with bovine viral diarrhea virus and Mannheimia haemolytica. J. Anim. Sci. 2011, 89, 1193-1200. [CrossRef]

15. Moya, D.; Holtshausen, L.; Marti, S.; Gibb, D.G.; McAllister, T.A.; Beauchemin, K.A.; Schwartzkopf-Genswein, K. Feeding behavior and ruminal $\mathrm{pH}$ of corn silage, barley grain, and corn dried distillers' grain offered in a total mixed ration or in a free-choice diet to beef cattle. J. Anim. Sci. 2014, 92, 3526-3536. [CrossRef]

16. DelCurto-Wyffels, H.; Dafoe, J.; Parsons, C.; Boss, D.; DelCurto, T.; Wyffels, S.; Van Emon, M.; Bowman, J. Corn versus Barley in Finishing Diets: Effect on Steer Performance and Feeding Behavior. Animals 2021, 11, 935. [CrossRef]

17. Barley Breeding Program, Montana. State University Malt Variety Dictionary-Hockett. 2008. Available online: https://www. montana.edu/barleybreeding/learning-center/malt-variety-dictionary/two-row/hockett.html (accessed on 10 December 2020).

18. Wang, Z.; Nkrumah, J.D.; Li, C.; Basarab, J.A.; Goonewardene, L.A.; Okine, E.K.; Crews, D.H.; Moore, S. Test duration for growth, feed intake, and feed efficiency in beef cattle using the GrowSafe System1. J. Anim. Sci. 2006, 84, 2289-2298. [CrossRef]

19. Gasteiner, J.; Guggenberger, T.; Häusler, J.; Steinwidder, A. Continuous and Long-Term Measurement of Reticuloruminal pH in Grazing Dairy Cows by an Indwelling and Wireless Data Transmitting Unit. Veter-Med. Int. 2012, 2012, 236956. [CrossRef] [PubMed]

20. Sowell, B.; Bowman, J.; Branine, M.; Hubbert, M. Radio frequency technology to measure feeding behavior and health of feedlot steers. Appl. Anim. Behav. Sci. 1998, 59, 277-284. [CrossRef]

21. Schwartzkopf-Genswein, K.; Atwood, S.; McAllister, T. Relationships between bunk attendance, intake and performance of steers and heifers on varying feeding regimes. Appl. Anim. Behav. Sci. 2002, 76, 179-188. [CrossRef]

22. Parsons, C.; Galyean, M.; Swingle, R.; DeFoor, P.; Nunnery, G.; Salyer, G. Use of Individual Feeding Behavior Patterns to Classify Beef Steers into Overall Finishing Performance and Carcass Characteristic Categories. Prof. Anim. Sci. 2004, 20, 365-371. [CrossRef]

23. Fox, J.; Weisberg, S. An R Companion to Applied Regression, 2nd ed.; Sage: Thousand Oaks, CA, USA, 2011. Available online: http:/ / socserv.socsci.mcmaster.ca/jfox/Books/Companion (accessed on 1 December 2020).

24. Bates, D.; Mächler, M.; Bolker, B.; Walker, S. Fitting Linear Mixed-Effects Models Using lme4. J. Stat. Softw. 2015, 67, 1-48. [CrossRef]

25. Lenth, R. Estimated Marginal Means, Aka Least-Squares Means, 1.3.3; R Package. 2019. Available online: https:/ /CRAN.Rproject.org / package=emmeans (accessed on 1 December 2020).

26. R Core Team. R: A Language and Environment for Statistical Computing; R Foundation for Statistical Computing: Vienna, Austria, 2018. Available online: https:/ / www.R-project.org/ (accessed on 15 November 2018).

27. Schwartzkopf-Genswein, K.; Beauchemin, K.; Gibb, D.; Crews, D.; Hickman, D.; Streeter, M.; McAllister, T. Effect of bunk management on feeding behavior, ruminal acidosis and performance of feedlot cattle: A review. J. Anim. Sci. 2003, 81, E149-E158. [CrossRef]

28. Cooper, R.J.; Klopfenstein, T.J.; Stock, R.A.; Milton, C.T.; Herold, D.W.; Parrott, J.C. Effects of imposed feed intake variation on acidosis and performance of finishing steers. J. Anim. Sci. 1999, 77, 1093-1099. [CrossRef]

29. Fulton, W.R.; Klopfenstein, T.J.; Britton, R.A. Adaptation to High Concentrate Diets by Beef Cattle. I. Adaptation to Corn and Wheat Diets. J. Anim. Sci. 1979, 49, 775-784. [CrossRef]

30. Surber, L.; Bowman, J.; Daniels, T.; Milner, T.; Lewis, A.; Coulson, D.; Blake, T. Feeding value of barley varieties for finishing cattle. In Proceedings of the Western Section American Society Animal Science, Denver, CO, USA, 27-30 July 1998; Volume 49, pp. 268-271.

31. Brown, M.S.; Krehbiel, C.R.; Galyean, M.L.; Remmenga, M.D.; Peters, J.P.; Hibbard, B.; Robinson, J.; Moseley, W.M. Evaluation of models of acute and subacute acidosis on dry matter intake, ruminal fermentation, blood chemistry, and endocrine profiles of beef steers. J. Anim. Sci. 2000, 78, 3155-3168. [CrossRef] [PubMed] 
32. Yang, W.; Beauchemin, K.; Koenig, K.; Rode, L. Comparison of Hull-less Barley, Barley, or Corn for Lactating Cows: Effects on Extent of Digestion and Milk Production. J. Dairy Sci. 1997, 80, 2475-2486. [CrossRef]

33. Overton, T.; Cameron, M.; Elliottt, J.; Clark, J.; Nelson, D. Ruminal Fermentation and Passage of Nutrients to the Duodenum of Lactating Cows Fed Mixture of Corn and Barley. J. Dairy Sci. 1995, 78, 1981-1998. [CrossRef]

34. Moya, D.; Mazzenga, A.; Holtshausen, L.; Cozzi, G.; González, L.A.; Calsamiglia, S.; Gibb, D.G.; McAllister, T.A.; Beauchemin, K.A.; Schwartzkopf-Genswein, K. Feeding behavior and ruminal acidosis in beef cattle offered a total mixed ration or dietary components separately1. J. Anim. Sci. 2011, 89, 520-530. [CrossRef]

35. Bewley, J.; Einstein, M.; Grott, M.; Schutz, M. Comparison of Reticular and Rectal Core Body Temperatures in Lactating Dairy Cows. J. Dairy Sci. 2008, 91, 4661-4672. [CrossRef] [PubMed]

36. Mohammed, R.; Hünerberg, M.; McAllister, T.A.; Beauchemin, K.A. Characterization of ruminal temperature and its relationship with ruminal $\mathrm{pH}$ in beef heifers fed growing and finishing diets1. J. Anim. Sci. 2014, 92, 4650-4660. [CrossRef]

37. Brod, D.L.; Bolsen, K.K.; Brent, B.E. Effect of Water Temperature in Rumen Temperature, Digestion and Rumen Fermentation in Sheep. J. Anim. Sci. 1982, 54, 179-182. [CrossRef] [PubMed]

38. Dye, T.; Richards, C. Effect of water consumption on rumen temperature. J. Dairy Sci. 2008, 86, 114.

39. Vázquez-Diosdado, J.; Miguel-Pacheco, G.; Plant, B.; Dottorini, T.; Green, M.; Kaler, J. Developing and evaluating threshold-based algorithms to detect drinking behavior in dairy cows using reticulorumen temperature. J. Dairy Sci. 2019, 102, 10471-10482. [CrossRef] [PubMed] 